\title{
Health Risk Assessment of Nitrate Pollution in Shallow Groundwater: A Case Study in China
}

\author{
Hui Tian ${ }^{1-3}$, Xiujuan Liang ${ }^{1,2 *}$, Yan Gong ${ }^{3}$, Linlin $\mathbf{Q i}^{1,2}$, Qiang Liu ${ }^{3}$, Zhuang Kang ${ }^{3}$, \\ Qifa Sun ${ }^{3}$, Hongtao Jin ${ }^{3}$
}

${ }^{1}$ Key Laboratory of Groundwater Resources and Environment, Ministry of Education, Jilin University, Changchun, China ${ }^{2}$ College of New Energy and Environment, Jilin University, Changchun, China

${ }^{3}$ Shenyang Geological Survey Center, China Geological Survey, Shenyang, China

Received: 13 January 2019

Accepted: 12 February 2019

\begin{abstract}
High concentrations of nitrate in groundwater pose a threat to human health. To quantify groundwater nitrate pollution in China's Lianhuashan District and evaluate its human health risks, 73 groundwater samples were collected and analyzed. Results showed that the spatial distribution of groundwater chemical components was varied and concentrations were in the order of $\mathrm{TDS}>\mathrm{HCO}>\mathrm{Ca}>\mathrm{Cl}>\mathrm{SO}_{4}>$ $\mathrm{Na}>\mathrm{Mg}>\mathrm{NO}_{3}>\mathrm{K}>\mathrm{NH}_{4}>\mathrm{NO}_{2} . \mathrm{NO}_{3}$ concentrations ranged from $0.02-340.49 \mathrm{mg} / \mathrm{L}$ and averaged $70.38 \mathrm{mg} / \mathrm{L}$. Over $28.76 \%$ of samples exceeded the QSCB Class III threshold (20 mg / L N). Principal component analysis determined that $\mathrm{NO}_{3}$ contamination was primarily attributed to the excessive use of fertilizers in agriculture. A human health risk assessment model was used to assess the potential health risks of groundwater $\mathrm{NO}_{3}$ via drinking water and skin contact pathways. Approximately $94 \%$ of adults, $86 \%$ of children, and $66 \%$ of infants had acceptable health risks. $\mathrm{NO}_{3}$ exposure risk in the towns of Quanyan and Quannongshan were the highest, while urban areas tended to have lower exposures. The health risks to residents, especially minors and infants, were concerning.
\end{abstract}

Keywords: groundwater contamination, human health risk assessment, nitrates, fertilizer overuse, China

\section{Introduction}

Groundwater is one of Earth's most precious natural resources [1]. It is vital to human health and the quality and quantity of grains because it affects soils, crops, and the surrounding environment $[1,2]$. However, due to environmental changes andhuman

*e-mail: 530325356@qq.com, 359585977@qq.com activities, groundwater quality is deteriorating at an alarming rate [3]. In recent years, the excessive use of chemical fertilizers and pesticides in agricultural areas hasbecome a major source of groundwater pollution, attracting considerable attention $[4,5]$.

Since 2006, China has become the world's largest producer and consumer of fertilizers. In 2016, global fertilizer consumption was approximately 187 million tons, of which China's consumption was 59.84 million tons $[6,7]$. The large-scale use of chemical fertilizers, 
especially the excessive use of nitrogen fertilizers, has led to an increase in groundwater nitrate pollution. According to a water resources survey conducted by Shenyang Geological Survey, China Geological Survey in the Songnen Plain, the nitrate over-standard rate was $28 \%$ and the over-standard area was $15.7 \%$. The average $\mathrm{NO}_{3}$ content in water resources reached $18.49 \mathrm{mg} / \mathrm{L}$, and individual survey points reached $70 \mathrm{mg} / \mathrm{L}$. According to studies, nitrate nitrogen in water has a more harmful effect on humans and aquatic organisms. For example, when water with a nitrate content of greater than $10 \mathrm{mg} / \mathrm{L}$ is consumed over time, methemoglobinemia occurs. A blood methemoglobin content of $70 \mathrm{mg} / \mathrm{L}$ results in suffocation. According to the results of the geological survey of the Changji Economic Circle during 2016-2018, the nitrate content (N) of groundwater in the study area ranged from $0-73.36 \mathrm{mg} / \mathrm{L}$. The high nitrate content of groundwater in this area is mainly caused by agricultural pollution. Groundwater nitrate pollution threatens human health and safety; therefore, it is necessary to expand the health risk assessment of groundwater to assess nitrate pollution, and provide a reference for groundwater management and pollution prevention $[8,9]$.

In rural areas, local residents directly draw from wells for drinking and irrigation. Their longterm exposure to groundwater with high nitrate concentrations has greatly increased the potential risk. Considering the serious impacts of groundwater nitrate pollution on human health, it is important to establish the relationship between groundwater nitrate and human health and to assess the degree of damage. This process is called the human health risk assessment (HHRA) model.

To characterize the current status of groundwater nitrate pollution in the Lianhuashan area, and quantitatively analyze the risk of groundwater nitrate pollution to human health, this study has the following aims. First, we determine the spatial distribution of major chemical parameters in the groundwater of the Lianhuashan area. Then, the relationship between groundwater chemistry and nitrate is analyzed using principal component analysis (PCA), and the nitrate contamination of groundwater is discussed. Finally, the HHRA model as recommended by the U.S. Environmental Protection Agency is used to assess the human health risks of nitrate contamination in groundwater. To reflect actual conditions, we consider both skin contact pathways and drinking water. Recipients (human) are divided into four groups (adult male, adult female, child, and infant). The results of this study will provide a basis for the management of groundwater resources in the government sector, and provide evidence for the appropriate use of nitrate fertilizers by the agricultural sector. In doing so, we hope to control groundwater nitrate pollution in agricultural areas, thus protecting the groundwater environment and human health.

\section{Materials and Methods}

\section{Study Area}

The Lianhuashan areais located in eastern Changchun City in northeastern China, and is attached to the southeastern edge of the Songnen Plains and to the west of the Jilin mountainous area. The study area is between $43^{\circ} 45^{\prime}$ and $44^{\circ} 57^{\prime} \mathrm{N}$, and $125^{\circ} 28^{\prime}$ and $125^{\circ} 50^{\prime}$ E, with an area of 417.00 square kilometers. The study area includes the towns of Quanyan to the northeast of Changchun City, Quannongshan to the southeast, and Sijiazi to the east (Fig. 1). The total population of the study area is about 0.59 million. The area is located in the mid-latitudes of the northern hemisphere and is a temperate continental semi-humid monsoon climate with four distinct seasons. The annual average temperature is $4.8^{\circ} \mathrm{C}$ and precipitation is between 522 and $615 \mathrm{~mm}$, which is mostly concentrated in JuneAugust (61\% of total annual precipitation) [10]. Annual average evaporation is $1239 \mathrm{~mm}$ and the study area is at an elevation of $250-350 \mathrm{~m}$. Terrain slopes from the southeast to the northwest. The surface water system has developed, forming a strip-shaped valley plain and a junction block. The Yitong and Yinma Rivers flow through the area, indicating that surface water resources are abundant. Aquifer lithology is mainly medium coarse sand and gravel, with a thickness of 2-3 m, covered with a weakly permeable sub-clay [11]. The change law of aqueous medium indicates that thickness increases from south to north, particles become thicker, water richness is stronger, and the groundwater level changes from 5 to $10 \mathrm{~m}$. The influence of meteorological factors and anthropogenic activities mean that groundwater in the region displays seasonal and cyclical changes. Groundwater recharge is mainly dependent on atmospheric precipitation and surface water while discharge occurs through mining and runoff excretion. Groundwater hydrochemical changes are affected by many aspects, including hydrology, topography, lithology, aquifer media, and human activities. Over the past few decades, the excessive use of chemical fertilizers in agricultural production has become an important source of groundwater pollution in the region.

\section{Sampling and Measurements}

Groundwater samples were taken from wells in rural areas mainly used for drinking. Sampling work lasted for two months, from June to August 2018. A total of 73 groundwater samples were collected and analyzed and their distribution is shown in Fig. 1. Due to the consistent hydrogeological conditions in the region, the spatial distribution of the sampling points was relatively uniform, which augurs well for objective conclusions. To accurately reflect the current groundwater conditions in the local area, it was necessary to pump water for 10 minutes at each sampling point prior to sample 


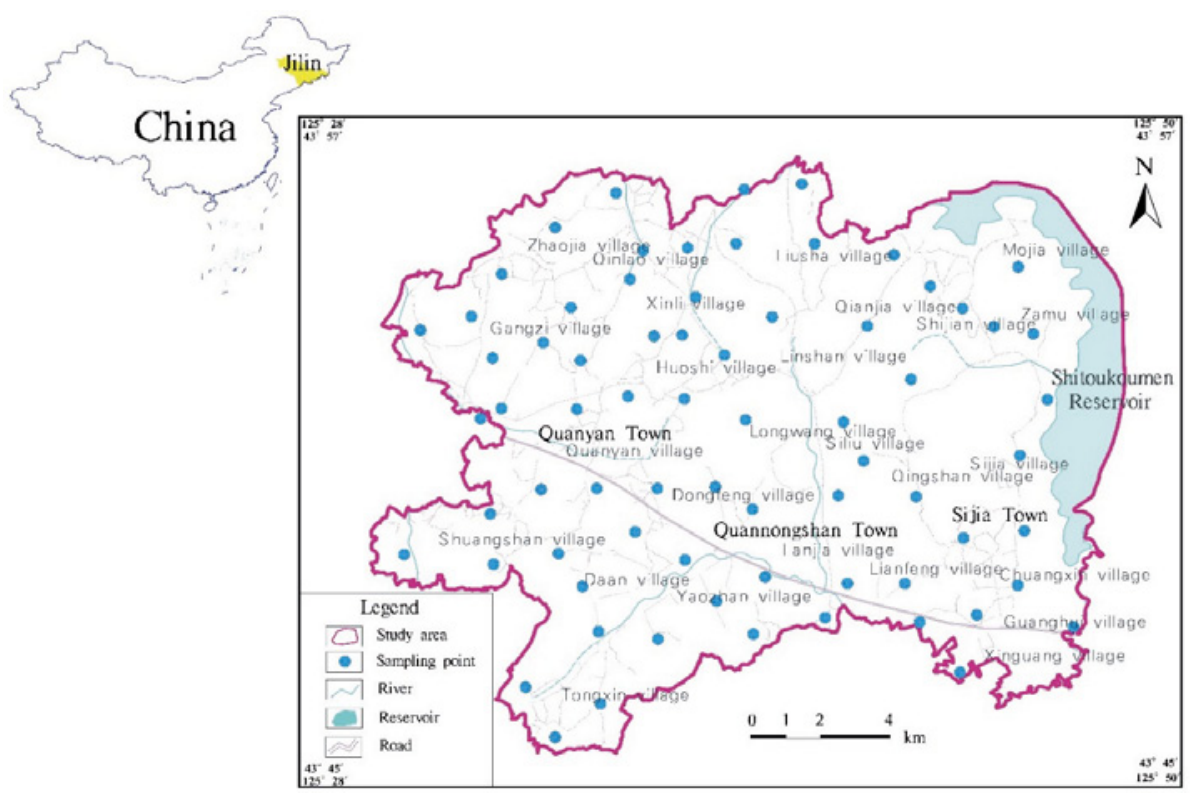

Fig. 1. Location and sampling sites of the study area.

collection. Samples were collected in bottles that were flushed three times with well water at the sampling point, filled, and sealed. The bottles were immediately stored in an incubator at $4^{\circ} \mathrm{C}$ for subsequent analysis.

Water temperature, $\mathrm{pH}$, dissolved oxygen, and total dissolved solids (TDS) were measured in the field using a calibrated multi-parameter water quality analyzer (HACH-HQ40D). The concentration of major cations $(\mathrm{Na}, \mathrm{K}, \mathrm{Ca}$, and $\mathrm{Mg}$ ) was determined in the laboratory using plasma spectroscopy (ICP-6300), and concentrations of major anions $\left(\mathrm{Cl}, \mathrm{SO}_{4}\right.$, and $\left.\mathrm{NO}_{3}\right)$ were determined in the laboratory using ion chromatography (ICS-3000). $\mathrm{NO}_{2}$ and $\mathrm{NH}_{4}$ concentrations were obtained using gas phase molecular absorption spectrometry (GMA-3376), and bicarbonate concentration was obtained by titration.

\section{Human Health Risk Assessment Model and Parameter Acquisition}

Health risk assessment describes the adverse health effects of human exposure to environmental hazards [12-18]. The human health risk assessment (HHRA) model is an evaluation method that assesses the risk of groundwater pollution to human health. It describes the degree of harm to the human body under various exposure pathways, and proposes recommendations to protect human health [19-26]. HHRA is based on four steps; hazard identification, dose-response assessment, exposure assessment, and risk characterization [27-35].

\section{Hazard Identification}

Hazard identification is the first step in HHRA. Its purpose is to identify the nature and strength of the source of risk. The hazard is the source of the risk and in this case refers to the ability of pollutants to cause adverse effects. This method of assessment requires the collection of large amounts of data, including natural background data from the study area, data on exposed populations, and contaminant data. To achieve this, detailed data were collected on the geography, geology, meteorology, hydrology, and hydrogeology of the study area. Through hydrogeological investigation in the study area and the use of groundwater dynamic monitoring data, the lithology, thickness, groundwater recharge, diameter, and drainage conditions of the aquifer were ascertained.

Data on exposed populations were obtained by collecting data on economic development, population size and composition, local residents' living habits, and land use in the study area. The degree of harm to human health by pollutants is not only related to the type and quantity of pollutants, but also to human activities in the assessment area. Hazard identification also analyzes whether groundwater contamination has an adverse effect on human health and an acceptable level of deviation in human health [36, 37].

Prior to evaluation, the status of pollutants in the evaluation area should be accurately quantified; including the source, type, concentration, and distribution of the pollutants plus their various physical and chemical parameters. Pollutants whose concentration exceeds the standard should be used as characteristic pollutants.

\section{Dose-Response Assessment}

Dose-response assessment is the process of quantitatively estimating the relationship between the exposure levels of harmful factors and the incidence of health effects in exposed populations. Dose effect 
evaluation is key to health risk assessment, and it is the basis for the quantitative assessment of health risk. The dose-effect relationship can be expressed by using the reference dose (RfD) [38]. The RfD is determined as follows:

$$
\mathrm{RfD}=\frac{N O A E L(L O C A E L)}{U F S}
$$

...where RfD, NOAEL, LOAEL, and UFs represents the chronic reference dose $(\mathrm{mg} / \mathrm{kg} / \mathrm{d})$, no observed adverse affect level $(\mathrm{mg} / \mathrm{kg} / \mathrm{d})$, lowest observed adverse affect level $(\mathrm{mg} / \mathrm{kg} / \mathrm{d})$, and uncertainty factors, respectively.

In this evaluation, the standard for groundwater nitrate is $10 \mathrm{mg} / \mathrm{L}$, the reference dose for oral intake of nitrate is $1.6 \mathrm{mg} / \mathrm{kg} \bullet \mathrm{d}$ [39], and the reference dose for nitrate skin intake is $0.8 \mathrm{mg} / \mathrm{kg} \mathrm{d}$ [40].

\section{Exposure Assessment}

Exposure assessment is the process of measuring human exposure to pollutants at medium intensity, frequency, and time to provide a quantitative basis for assessment. The main assessment components include exposure media, exposure time, concentration and distribution of pollutants, the method and time of pollutant transport, receptor exposure, and environmental concentration.

Combined with the health risk assessment model, the ingested and inhaled exposure doses were determined [41]. Using a questionnaire survey during the process of collecting water samples, drinking water and dermal contact were assumed to be the two main exposure pathways. Thus, chronic daily intake (CDI; $\mathrm{mg} / \mathrm{kg} / \mathrm{d}$ ) and dermal absorbed dose (DAD; $\mathrm{mg} / \mathrm{kg} / \mathrm{d}$ ) were calculated.

The intake of potentially harmful substances through the drinking water pathway, expressed as CDI, is calculated as follows [42]:

$$
\mathrm{CDI}=\frac{C W \times I R \times E F \times E D}{B W \times A T}
$$

...where CDI is the exposure $(\mathrm{mg} / \mathrm{kg} \mathrm{d})$, expressed as the mass of the substance contacted per unit time; $\mathrm{Cw}$ is the average concentration of the pollutant in water $(\mathrm{mg} / \mathrm{L})$; IR is the amount of water intake per day (L/d), as shown in Table 1; EF is the exposure frequency (d/a); ED is the average exposure duration, generally expressed in years (years); BW is the average individual weight $(\mathrm{kg})$, and AT is the average time in days $(\mathrm{AT}=365 \times \mathrm{ED}, \mathrm{d})$.

The amount of potential toxins ingested by the human body through skin contact is indicated by DAD $(\mathrm{mg} / \mathrm{kg} \bullet \mathrm{d})$ as follows [44]:

$$
\mathrm{DAD}=\frac{C W \times K i \times S A \times E F \times E D \times E V \times C F}{B W \times A T}
$$

...where DAD is the dose of harmful substances absorbed by skin contact $(\mathrm{mg} / \mathrm{kg} \bullet \mathrm{d})$; $\mathrm{CW}$ is the concentration of pollutants in groundwater $(\mathrm{mg} / \mathrm{L}) ; \mathrm{Ki}$ is the permeability coefficient of dermal $(\mathrm{cm} / \mathrm{h})$ in water; $\mathrm{EF}$ is the exposure frequency $(\mathrm{d} / \mathrm{a})$; SA is the skin surface area $\left(\mathrm{cm}^{2}\right)$ available for contact; ED is the average exposure duration (years); EV is the bath frequency (times/d); CF is the unit conversion factor $\left(\mathrm{L} / \mathrm{cm}^{3}\right)$; AT is Average time (days); and BW is the average body weight $(\mathrm{kg})$.

\section{Risk Characterization}

Risk characterization is the process of calculating the magnitude of the health hazard, or the probability of a certain health effect under different conditions, using the data obtained in the previous three stages. Through comprehensive analysis and uncertainty analysis of data and parameters, the probability of occurrence of risks and the acceptable risk characteristics of human beings

\begin{tabular}{|c|c|c|c|c|}
\hline \multirow{2}{*}{ Age Group (L/d) } & \multirow{2}{*}{ Average Value (L/d) } & \multicolumn{3}{|c|}{ Percentage Distribution (L/d) } \\
\hline & & $50^{\text {th }}$ & $90^{\text {th }}$ & $95^{\text {th }}$ \\
\hline 1 year old & 0.30 & 0.24 & 0.65 & 0.76 \\
\hline 3 year old & 0.61 & - & 1.50 & - \\
\hline $3-5$ year old & 0.87 & - & 1.50 & - \\
\hline $5-10$ year old & 0.74 & 0.66 & 1.30 & 1.50 \\
\hline 11-19 year old & 0.97 & 0.87 & 1.70 & 2.00 \\
\hline Youth & 1.40 & 1.30 & 2.30 & - \\
\hline Pregnant woman & 1.20 & 1.10 & 2.20 & 2.40 \\
\hline Breast Feeding Women & 1.30 & 1.30 & 1.90 & 2.20 \\
\hline Young people (heat or strenuous) & $0.21-0.65$ & & & \\
\hline Young people (activity) & 0.60 & & & \\
\hline
\end{tabular}
are determined. The potential non-carcinogenic risk of

Table 1. Recommended drinking water volumes for different age groups.

These data come from Zhang et al. (2008) [43]. 
Table 2. Reference values for exposure duration.

\begin{tabular}{|c|c|c|}
\hline Exposure Receptor & $\begin{array}{c}\text { Exposure } \\
\text { Duration(a) }\end{array}$ & Unit \\
\hline Child Resident & 6 & U.S.EPA 1990f;1994r \\
\hline Adult Resident & 30 & U.S.EPA 1990f;1995r \\
\hline Fisher & 30 & U.S.EPA 1990f;1996r \\
\hline Farmer & 40 & U.S.EPA 1990f;1997r \\
\hline Farmer child & 6 & U.S.EPA 1990f;1998r \\
\hline
\end{tabular}

nitrate was assessed by calculating the hazard quotient (HQ) of contaminant intake (oral and skin) and RfD [41]. The greater the HQ value, the greater the harm to human health.

Regarding the health risk assessment of nitrates, the oral hazard quotient can be expressed as:

$$
\text { HQoral }- \text { water }=\frac{C D I}{\text { RfDoral }- \text { water }}
$$

...where HQoral-water indicates a non-carcinogenic hazard by ingestion of water (non-dimensional);
RfDoral-water is the reference dose of water intake $(\mathrm{mg} / \mathrm{kg} \bullet \mathrm{d})$, select 1.6; and CDI is a daily chronic intake $(\mathrm{mg} / \mathrm{kg} \cdot \mathrm{d})$.

Regarding the health risk assessment of nitrates, the dermal hazard quotient can be expressed as:

$$
\text { HQderm }- \text { water }=\frac{C D I}{\text { RfDderm -water }}
$$

...where HQderm-water is non-carcinogenic dermal hazard quotient through dermal absorption of water (non-dimensional); RfDderm-water is reference dose of the dermal absorption ( $\mathrm{mg} / \mathrm{kg} \mathrm{d}$ ), select 1.0; and DAD is dermal absorbed dose $(\mathrm{mg} / \mathrm{kg} \bullet \mathrm{d})$.

Regarding the health risk assessment of nitrates, the total hazard quotient can be expressed as:

$$
\text { HQ = HQoral-water }+ \text { HQderm-water }
$$

...where HQ is the total hazard quotient (nondimensional); HQderm-water is non-carcinogenic dermal hazard quotient (non-dimensional); and HQoralwater is non-carcinogenic oral hazard quotient (non-

\begin{tabular}{|c|c|c|c|c|c|c|c|c|c|}
\hline \multirow[b]{2}{*}{ Age } & \multicolumn{4}{|c|}{ Weight (kg) } & \multirow[b]{2}{*}{ Age } & \multicolumn{4}{|c|}{ Weight (kg) } \\
\hline & $\begin{array}{l}\text { Rural } \\
\text { Male }\end{array}$ & $\begin{array}{l}\text { Rural } \\
\text { Female }\end{array}$ & $\begin{array}{l}\text { Urban } \\
\text { Male }\end{array}$ & $\begin{array}{l}\text { Urban } \\
\text { Female }\end{array}$ & & $\begin{array}{l}\text { Rural } \\
\text { Male }\end{array}$ & $\begin{array}{l}\text { Rural } \\
\text { Female }\end{array}$ & $\begin{array}{l}\text { Urban } \\
\text { Male }\end{array}$ & $\begin{array}{l}\text { Urban } \\
\text { Female }\end{array}$ \\
\hline 1 mouth & 5.30 & 5.30 & 5.40 & 5.20 & 9 years & 30.40 & 28.60 & 26.10 & 25.40 \\
\hline 2 mouths & 6.30 & 6.00 & 6.20 & 5.60 & 10 years & 33.80 & 32.80 & 28.60 & 28.20 \\
\hline 3 mouths & 7.10 & 6.80 & 6.90 & 6.30 & 11 years & 37.40 & 36.70 & 31.90 & 31.80 \\
\hline 4 mouths & 7.60 & 6.80 & 7.50 & 7.30 & 12 years & 40.50 & 40.50 & 35.40 & 35.80 \\
\hline 5 mouths & 8.30 & 7.60 & 8.00 & 7.40 & 13 years & 44.90 & 44.90 & 39.30 & 40.50 \\
\hline 6 mouths & 8.70 & 8.30 & 8.60 & 8.10 & 14 years & 49.40 & 49.40 & 45.10 & 44.10 \\
\hline 8 mouths & 9.50 & 9.00 & 9.20 & 8.70 & 15 years & 55.20 & 55.20 & 48.60 & 46.70 \\
\hline 10 mouths & 10.20 & 9.10 & 9.50 & 8.90 & 16 years & 57.20 & 57.20 & 53.00 & 49.20 \\
\hline 12 mouths & 10.40 & 9.90 & 9.90 & 9.60 & 17 years & 58.70 & 58.70 & 54.90 & 51.20 \\
\hline 15 mouths & 10.80 & 10.10 & 10.50 & 9.80 & 18 years & 60.90 & 60.90 & 56.80 & 51.70 \\
\hline 18 mouths & 11.70 & 11.00 & 11.00 & 10.40 & 19 years & 61.20 & 61.20 & 58.80 & 52.30 \\
\hline 21 mouths & 12.40 & 11.60 & 11.70 & 11.10 & 20 years & 65.70 & 65.70 & 61.80 & 52.70 \\
\hline 2 years & 13.50 & 12.70 & 12.80 & 11.90 & 30 years & 67.50 & 67.50 & 63.20 & 54.70 \\
\hline 3 years & 16.00 & 15.40 & 14.30 & 13.80 & 40 years & 67.70 & 67.70 & 62.10 & 56.00 \\
\hline 4 years & 17.80 & 17.00 & 16.00 & 15.50 & 50 years & 67.20 & 67.20 & 60.50 & 55.00 \\
\hline 5 years & 19.70 & 19.00 & 17.70 & 17.10 & 60 years & 66.60 & 66.60 & 58.20 & 51.40 \\
\hline 6 years & 22.20 & 21.10 & 19.40 & 18.70 & 70 years & 63.50 & 63.50 & 55.50 & 48.60 \\
\hline 7 years & 24.80 & 23.20 & 21.70 & 20.60 & 80 years & 59.40 & 59.40 & 53.50 & 46.50 \\
\hline 8 years & 27.20 & 26.00 & 23.90 & 22.90 & - & & & & \\
\hline
\end{tabular}
dimensional).

Table 3. Statistics on the weight of Chinese residents in 2002.

The data comes from the National Bureau of Statistics of the People's Republic of China, 2003. 
Table 4. Statistics on the weight of Chinese residents in 2002.

\begin{tabular}{|c|c|c|c|c|c|c|}
\hline \multirow{2}{*}{\multicolumn{2}{|c|}{ Parameter Meaning }} & \multicolumn{4}{|c|}{ Value } & \multirow{3}{*}{$\begin{array}{l}\text { Unit } \\
\text { L/d }\end{array}$} \\
\hline & & \multirow{2}{*}{$\begin{array}{c}\text { Males } \\
-\end{array}$} & \multirow{2}{*}{$\begin{array}{c}\text { Females } \\
-\end{array}$} & \multirow{2}{*}{$\frac{\text { Children }}{1.5^{\mathrm{b}}}$} & \multirow{2}{*}{$\begin{array}{c}\text { Infants } \\
0.65^{\mathrm{d}}\end{array}$} & \\
\hline IR & Amount of drinking water & & & & & \\
\hline $\mathrm{EF}$ & Exposure frequency & $365^{b}$ & & & & $\mathrm{~d} / \mathrm{a}$ \\
\hline ED & Exposure duration & $30^{\mathrm{b}}$ & $30^{\mathrm{b}}$ & $6^{\mathrm{b}}$ & $0.5^{\mathrm{d}}$ & $\mathrm{a}$ \\
\hline BW & Average body weight & $69.55^{\mathrm{a}}$ & $60.4^{\mathrm{a}}$ & - & - & $\mathrm{kg}$ \\
\hline AT & Average exposure time & 10950 & 10950 & 2190 & $182.5^{\mathrm{d}}$ & d \\
\hline SA & Body surface areas & $1700^{\mathrm{a}}$ & $1600^{\mathrm{a}}$ & 9035.2 & 3416 & $\mathrm{~cm}^{2}$ \\
\hline $\mathrm{EV}$ & Bathing frequency & \multicolumn{4}{|c|}{$1^{\mathrm{c}}$} & time/d \\
\hline $\mathrm{CF}$ & Unit conversion facter & \multicolumn{4}{|c|}{$0.002^{c}$} & $\mathrm{~L} / \mathrm{cm}^{3}$ \\
\hline $\mathrm{Ki}$ & Dermal adsorption & \multicolumn{4}{|c|}{$0.001^{\mathrm{c}}$} & $\mathrm{cm} / \mathrm{h}$ \\
\hline
\end{tabular}

a These data come from Ministry of Environmental Protection of the People's Republic of China (2013).

b These data come from Su et al. (2013)[10].

c These data come from Yang et al. (2012)[40].

d These data come from Zhang (2008)[43].

The study population was divided into four categories: adult males, adult females, children (2-17 years old), and infants (less than 1 year old). The exposure parameter values were from the U.S. Environmental Protection Agency, as shown in Table 3. The weight information of residents (Table 3 ) is from official Chinese statistics. Other parameters required for the evaluation are shown in Table 4.
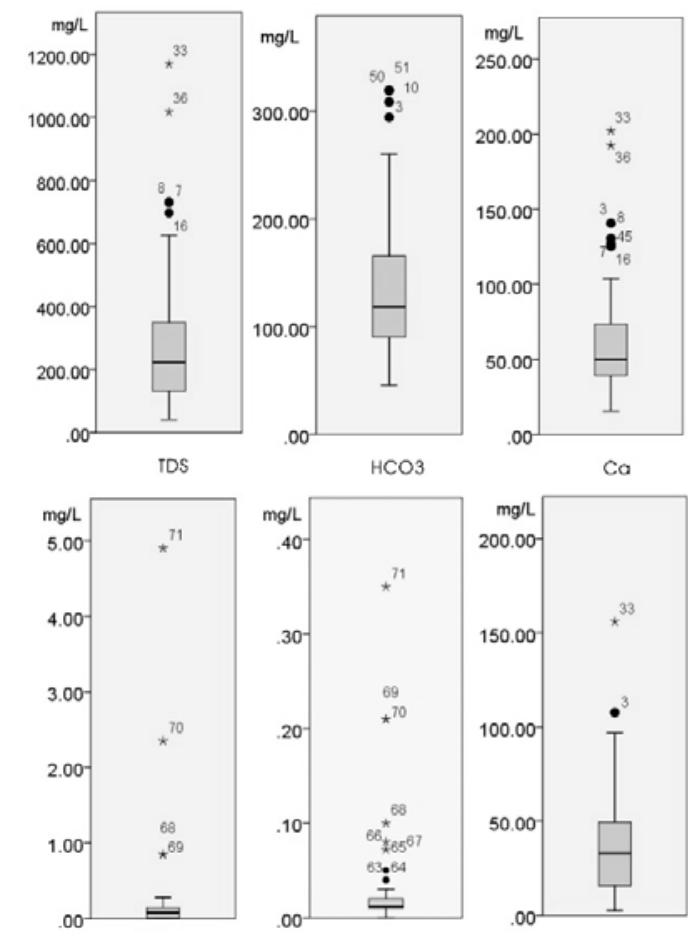

NH4

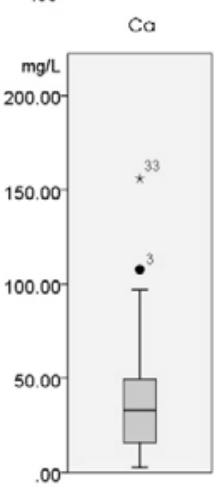

SO4

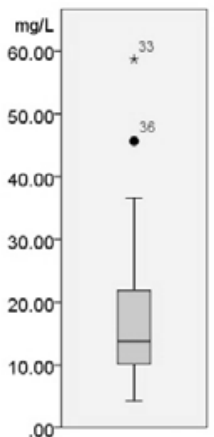

$\mathrm{Mg}$

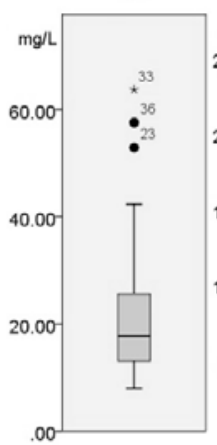

$\mathrm{Na}$

\section{Statistical Analysis}

PCA (SPSS 17) was used to analyze the relationship between the chemical type of groundwater and $\mathrm{N}$ concentration. This approach reveals the similarities between the different chemical components of groundwater. PCA can classify complex factors into several principal components, and analyze the relationship between variables and samples [13].

Fig. 2. Box plots of the concentration distributions of groundwater chemical indicators in the study area. 


\section{Results and Discussion}

\section{General Characteristics of Groundwater Chemistry}

The chemical nature of groundwater determines its use in either domestic, industrial, or agricultural applications. It also has an impact on the study of groundwater pollutant concentration, presence, migration, and transformation. Statistical information on the physicochemical properties of groundwater samples in the study area is shown in Fig. 2. The concentrations of the analyzed parameters are in the order of TDS $>$ $\mathrm{HCO}_{3}>\mathrm{Ca}>\mathrm{Cl}>\mathrm{SO}_{4}>\mathrm{Na}>\mathrm{Mg}>\mathrm{NO}_{3}>\mathrm{K}>\mathrm{NH}_{4}>\mathrm{NO}_{2}$.

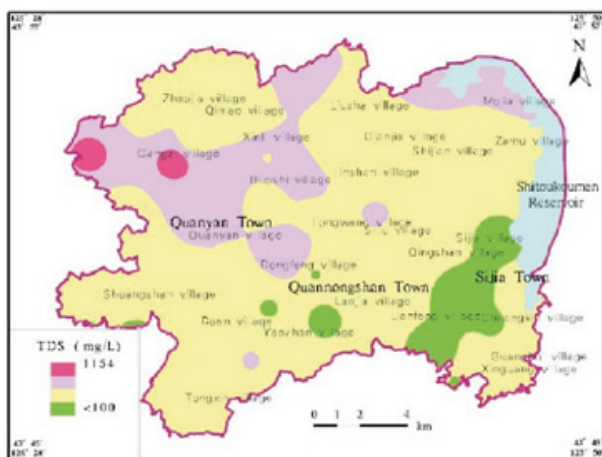

a)
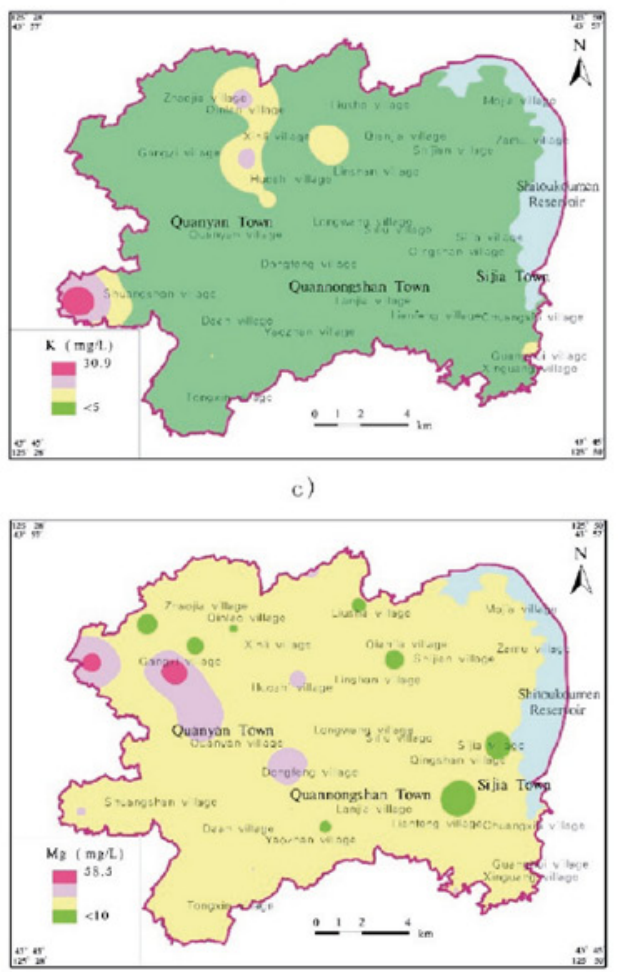

e)

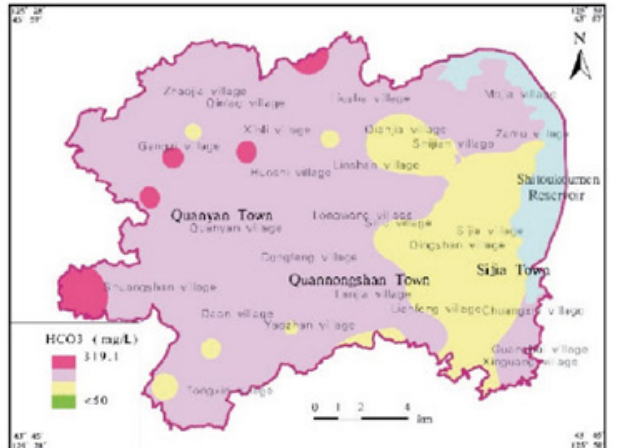

g)

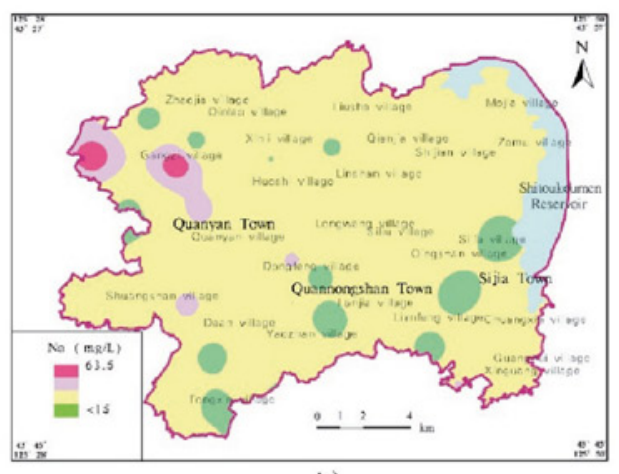

b)

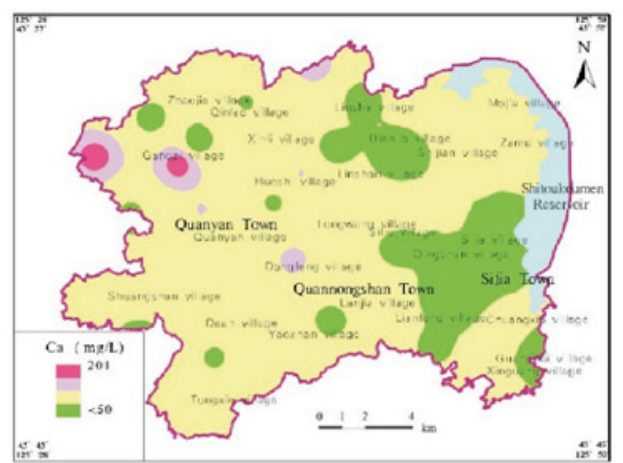

d)

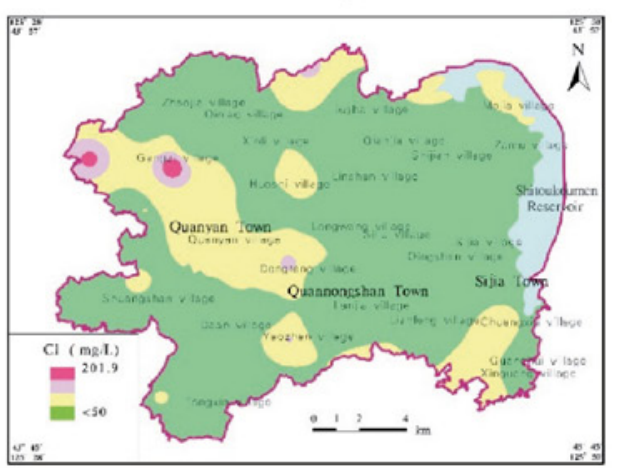

f)

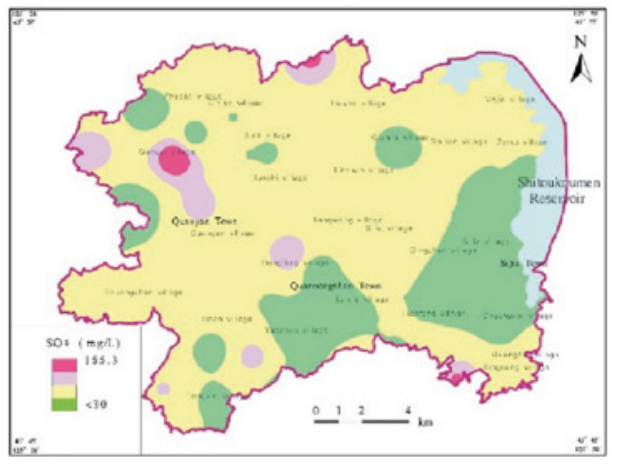

h)

Fig. 3. Spatial distributions of groundwater chemical indexes (TDS, $\mathrm{K}, \mathrm{Na}, \mathrm{Ca}, \mathrm{Mg}, \mathrm{SO}_{4}, \mathrm{Cl}$, and $\mathrm{HCO}_{3}$ ). 
Their concentration differs spatially (Fig. 3), reflecting the degree of data distribution at the sample points.

The $\mathrm{pH}$ range determines the extent to which groundwater is disturbed on a spatial scale. The maximum, minimum and mean groundwater $\mathrm{pH}$ values are $7.19,6.25$, and 6.71 , respectively, indicating that the water environment is weakly acidic. TDS indicates thetotal solids dissolved in the aqueous solution. Fig. 4 shows that the average concentration of TDS in the study area is $276 \mathrm{mg} / \mathrm{L}$. The highest concentration of TDS is $1169 \mathrm{mg} / \mathrm{L}$, in Gangzi Village, Quanyan Town. According to QSGC, approximately $12.32 \%$ of TDS samples exceed Class III values (Fig. 4). Overall, the TDS content of groundwater in the study area is relatively low and suitable for consumption. The main components of groundwater include $\mathrm{K}, \mathrm{Na}, \mathrm{Ca}, \mathrm{Mg}$, $\mathrm{HCO}_{3}, \mathrm{Cl}$, and $\mathrm{SO}_{4}$, which determine the chemical type and spatial distribution of groundwater. The average concentration of $\mathrm{Na}$ ions is $20.91 \mathrm{mg} / \mathrm{L}$, and the maximum concentration is $63.69 \mathrm{mg} / \mathrm{L}$ in the Gangzi Village and the western part of Quanyan Town. The average concentration of $\mathrm{K}$ was $3.21 \mathrm{mg} / \mathrm{L}$ and the maximum concentration was $31.08 \mathrm{mg} / \mathrm{L}$. Overall, the $\mathrm{K}$ content in most parts of the study area was less than $3 \mathrm{mg} / \mathrm{L}$. The average concentration of $\mathrm{Mg}$ is $16.67 \mathrm{mg} / \mathrm{L}$, and the minimum concentration is $4.28 \mathrm{mg} / \mathrm{L}$. Mg concentrations in the middle of Quanyan Town and the northwestern part of Quannongshan Town were the highest, up to $58.69 \mathrm{mg} / \mathrm{L}$. The spatial variability of $\mathrm{Ca}$ is largely consistent with $\mathrm{Mg}$. Generally, the concentration of $\mathrm{Ca}$ is the highest of the cations and its concentration is high throughout the study area. The concentration values of $\mathrm{Ca}$ at $45 \%$ of the sampling sites exceeded $60 \mathrm{mg} / \mathrm{L}$, and the highest value was $202 \mathrm{mg} / \mathrm{L}$. The chemical composition of groundwater in the study area is mainly affected by the interaction of water and rock, especially the dissolution of carbonate and gypsum, and the precipitation of calcite. Reverse ion exchange and mineral dissolution also impact the groundwater concentrations of $\mathrm{Na}, \mathrm{K}, \mathrm{Ca}$, and $\mathrm{Mg}$ in the study area.

The concentrations of $\mathrm{SO}_{4}$ and $\mathrm{Cl}$ are relatively uniform throughout the study area. The average concentration of $\mathrm{SO}_{4}$ was $36.61 \mathrm{mg} / \mathrm{L}$, and the
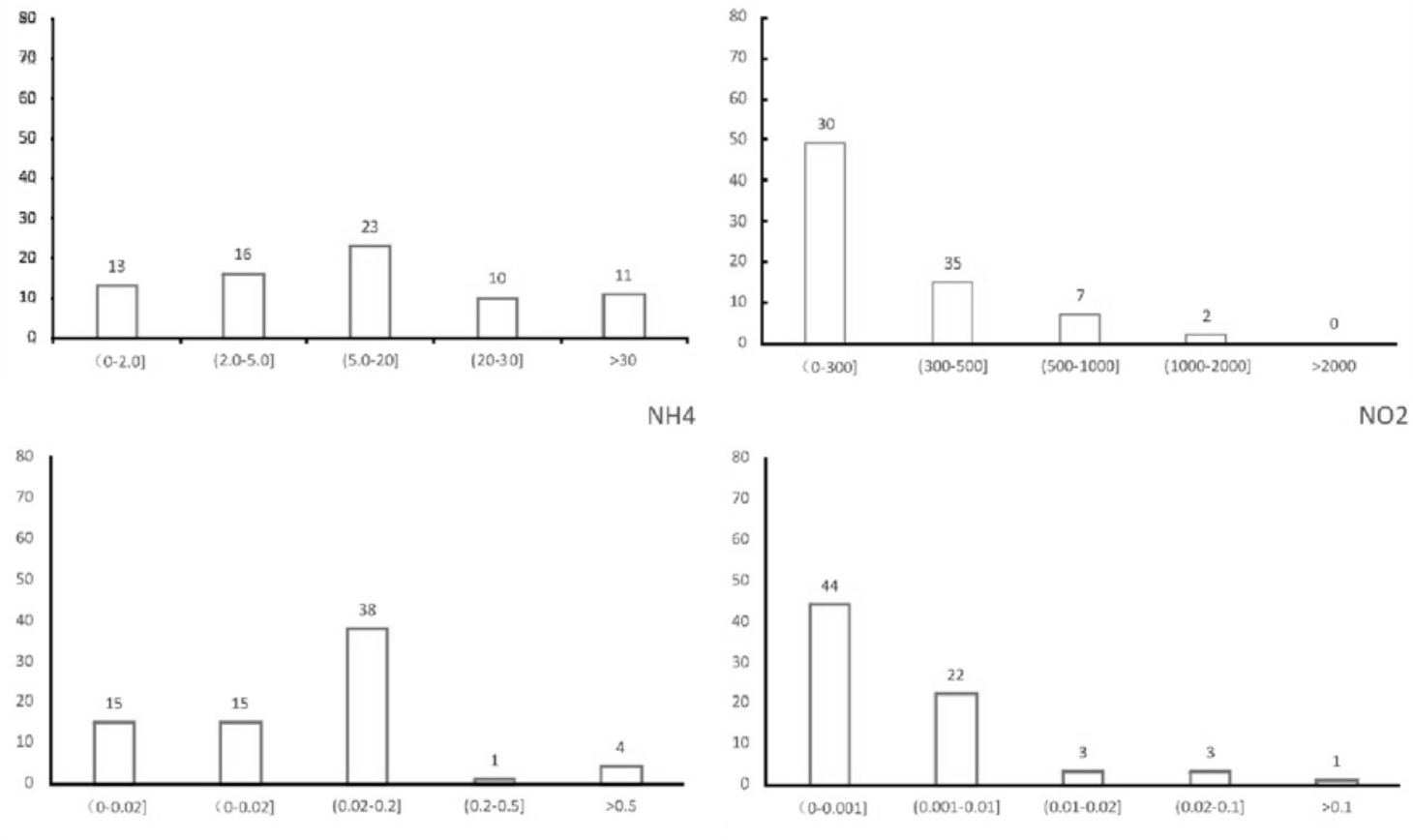

$\mathrm{SO} 4$
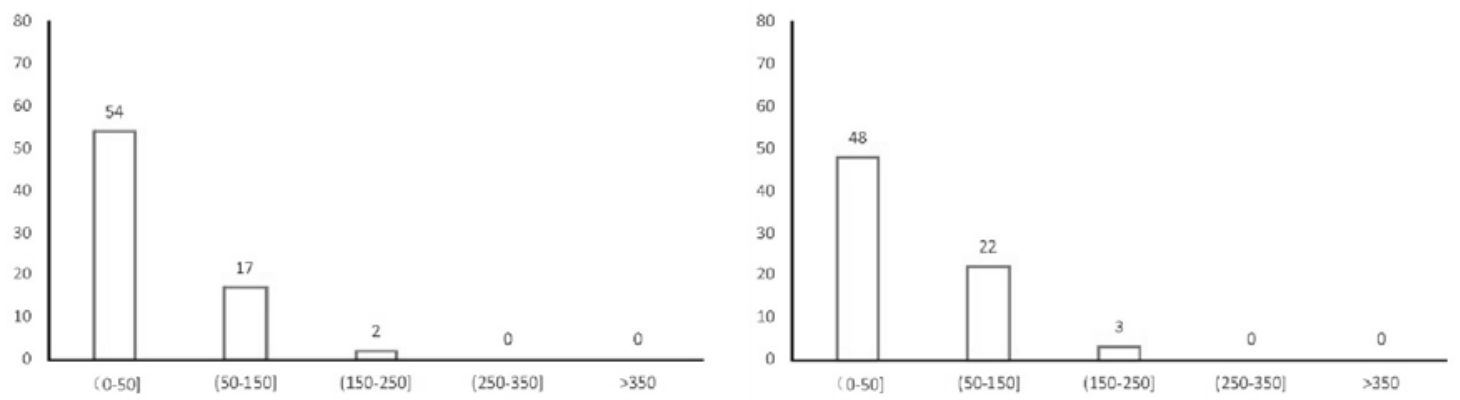

Fig. 4. Bar charts of different anions in groundwater chemical indexes (the standard of classification is adopted from QSGC). 


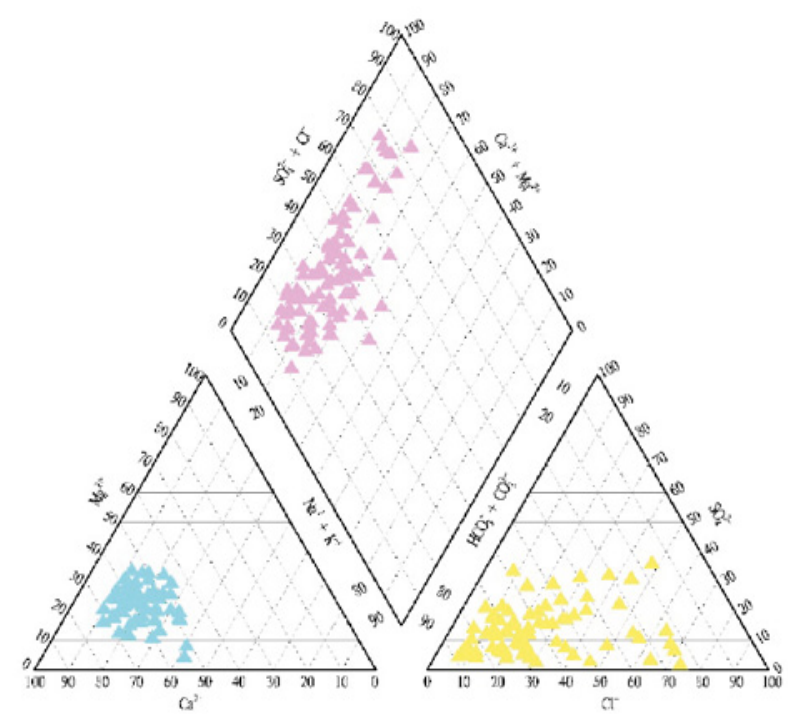

Fig. 5. Piper diagrams of the groundwater hydrochemical type in the study area.

maximum value was $155.84 \mathrm{mg} / \mathrm{L}$ in Gangzi village, Quanyan town. The average concentration of $\mathrm{Cl}$ was $44.17 \mathrm{mg} / \mathrm{L}$, and the maximum value was $202.50 \mathrm{mg} / \mathrm{L}$ in Gangzi village. $\mathrm{HCO}_{3}$ concentrations change markedly in Shuangshan village and Xinli village, and the highest value reaches $319 \mathrm{mg} / \mathrm{L}$. Spatial differences in the distribution of anions are apparent; $\mathrm{HCO}_{3}$ are the highest in the area of the southwestern platform while $\mathrm{Cl}$ and $\mathrm{SO}_{4}$ are the highest in the northwestern region. According to QSGC evaluation criteria, approximately $4.10 \%$ of $\mathrm{Cl}$ and $2.74 \%$ of the $\mathrm{SO}_{4}$ sampling points exceeded the corresponding Class III values (Fig. 4).

To accurately reflect and describe groundwater chemistry in the study area, a Piper three-line diagram was drawn using MapGIS 6.7 software (Fig. 5). The main ions of each water sample are projected into the diamond-shaped area, and the results represent the type of groundwater. The Piper diagram shows that cations in the groundwater are dominated by $\mathrm{Ca}$ and $\mathrm{Na}$, and $\mathrm{HCO}_{3}$ and $\mathrm{Cl}$ are the main anions. In short, the region's water chemistry is relatively simple, and the study area is mainly composed of $\mathrm{Ca} \cdot \mathrm{Na}-\mathrm{HCO}_{3} \cdot \mathrm{Cl}$-type water.

\section{Groundwater Nitrate Pollution}

Fig. 3 shows statistical data for trinitrogen. $\mathrm{NH}_{4}$ concentrations ranged from $0.01-3.81 \mathrm{mg} / \mathrm{L}$ with an average of $0.16 \mathrm{mg} / \mathrm{L}$. Concentrations in $52.05 \%$ of samples exceeded Grade III levels $(0.2 \mathrm{mg} / \mathrm{L}$ of $\mathrm{N}$; Fig. 4). Less than $6.85 \%$ of the $\mathrm{NH}_{4}$ concentration exceeds $0.2 \mathrm{mg} / \mathrm{L} .97 .26 \%$ of the samples have an $\mathrm{NH}_{4}$ concentration of less than $1.0 \mathrm{mg} / \mathrm{L}$, reflecting a relatively stable spatial distribution (Fig. 3). The concentration of $\mathrm{NO}_{2}$ ranged from $0-0.35 \mathrm{mg} / \mathrm{L}$ with an average of $0.03 \mathrm{mg} / \mathrm{L}$. Concentrations in $9.58 \%$ of

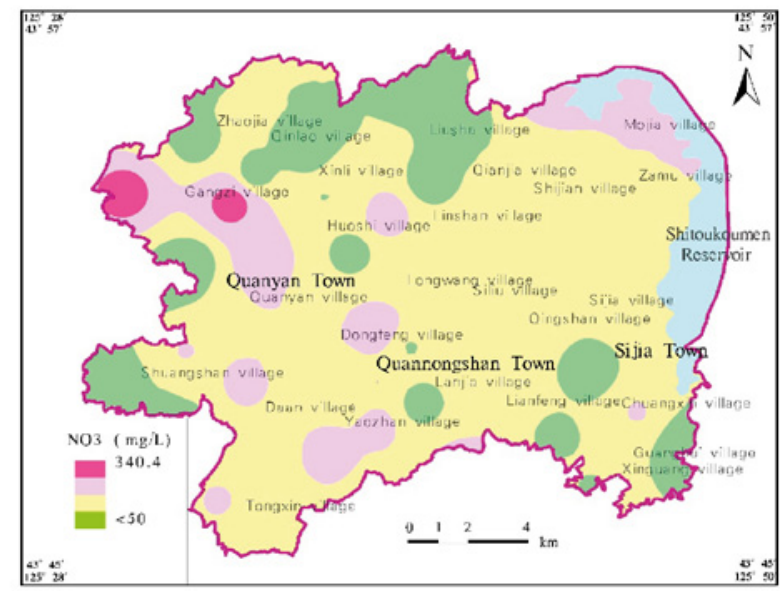

Fig. 6. Distribution of nitrate concentration in the study area.

samples exceeded the Grade III value $(0.02 \mathrm{mg} / \mathrm{L}$ of $\mathrm{N}$; Fig. 3). Less than $2.74 \%$ of samples exceeded $\mathrm{NO}_{2}$ concentrations of $0.3 \mathrm{mg} / \mathrm{L}$, indicating that the $\mathrm{NO}_{2}$ content in most of the region was relatively stable (Fig. 3). Compared to $\mathrm{NO}_{2}$ and $\mathrm{NH}_{4}, \mathrm{NO}_{3}$ showed marked spatial variability. Concentration values ranged from $0.00-340.49 \mathrm{mg} / \mathrm{L}$ with an average of $70.38 \mathrm{mg} / \mathrm{L}$ (Fig. 6) and more than $28.76 \%$ of samples exceeded Grade III values $(20 \mathrm{mg} / \mathrm{L}$ of $\mathrm{N})$. Results suggest that there is a high degree of groundwater contamination in the study area.

The correlation matrix between various groundwater components was calculated using SPSS17 software (Table 5). According to Zakhem and Hafez [45], the correlation coefficient $\left(\mathrm{R}^{2}\right)$ was $0.5 . \mathrm{NO}_{3}$ is positively correlated with $\mathrm{Ca}\left(\mathrm{R}^{2}=0.80\right)>\mathrm{Cl}\left(\mathrm{R}^{2}=0.76\right)>\mathrm{SO}_{4}$ $\left(\mathrm{R}^{2}=0.40\right)$. The positive correlation between $\mathrm{NO}_{3}$ and $\mathrm{Ca}$ suggest that the high concentration of $\mathrm{NO}_{3}$ is related to fertilizer and agricultural production [46], and the high correlation between $\mathrm{NO}_{3}$ and $\mathrm{Cl}$ suggests that the use of organic fertilizers results in a high concentration of $\mathrm{NO}_{3}$ [47]. The correlation between $\mathrm{NO}_{3}$ and $\mathrm{SO}_{4}$ is high and is related to the discharge of domestic sewage [48]. There is a negative correlation between $\mathrm{NO}_{3}$ and $\mathrm{HCO}_{3}$, indicating that denitrification of groundwater is caused by human disturbance, rather than the interaction of groundwater and protoliths $[47,49]$. Based on this data, we conclude that the use of agricultural fertilizers and the discharge of domestic sewage are the main sources of increased $\mathrm{NO}_{3}$ in the region's groundwater [50, 51]. Correlation analysis reveals that human activities are a key factor behind the high levels of $\mathrm{NO}_{3}$ in the study area.

\section{Health Risks of Adult Males and Females}

HHRA was used to calculate the health risks of the region's adult population. The spatial distribution of HQ values for adult males and females are shown in Figs 7 and 8. HQ values for adult males range 0-1.04; 
Table 5. Relationship between various groundwater chemical parameters in the study area.

\begin{tabular}{|c|c|c|c|c|c|c|c|c|c|c|}
\hline $\begin{array}{c}\text { Param- } \\
\text { eter }\end{array}$ & $\mathrm{TDS}$ & $\mathrm{pH}$ & $\mathrm{K}$ & $\mathrm{Na}$ & $\mathrm{Ca}$ & $\mathrm{Mg}$ & $\mathrm{SO}_{4}$ & $\mathrm{Cl}$ & $\mathrm{HCO}_{3}$ & $\mathrm{NO}_{3}$ \\
\hline $\mathrm{TDS}$ & 1.00 & & & & & & & & \\
\hline $\mathrm{pH}$ & -0.59 & 1.00 & & & & & & & & \\
\hline $\mathrm{K}$ & -0.04 & 0.24 & 1.00 & & & & & & & \\
\hline $\mathrm{Na}$ & 0.75 & -0.44 & 0.11 & 1.00 & & & & & & \\
\hline $\mathrm{Ca}$ & 0.84 & -0.49 & 0.00 & 0.72 & 1.00 & & & & & \\
\hline $\mathrm{Mg}$ & 0.77 & -0.40 & 0.18 & 0.73 & 0.93 & 1.00 & & & & \\
\hline $\mathrm{SO}$ & 0.71 & -0.41 & -0.01 & 0.73 & 0.69 & 0.71 & 1.00 & & & \\
\hline $\mathrm{Cl}_{4}$ & 0.79 & -0.55 & -0.12 & 0.74 & 0.93 & 0.87 & 0.69 & 1.00 & & \\
\hline $\mathrm{HCO}_{3}$ & 0.28 & 0.06 & 0.61 & 0.39 & 0.32 & 0.38 & 0.26 & 0.14 & 1.00 & \\
\hline $\mathrm{NO}_{3}$ & 0.66 & -0.46 & -0.17 & 0.53 & 0.80 & 0.75 & 0.40 & 0.76 & -0.19 & 1.00 \\
\hline
\end{tabular}

and the health risk in $98 \%$ of the study area is at acceptable levels. However, a health risk from $\mathrm{NO}_{3}$ pollution exists in a small region to the northwest of Quanyan town. In other words, groundwater $\mathrm{NO}_{3}$ pollution generally does not present a hazard to adult males in the region. HQ values for adult women range $0-1.19$, and approximately $94 \%$ of the study area is at acceptable exposure levels. Hence, the region's adult women are slightly more exposed to health risks from groundwater $\mathrm{NO}_{3}$ as compared to adult males. We conclude that groundwater $\mathrm{NO}_{3}$ pollution in the study area presents a low hazard to the adult population; however, approximately $6 \%$ of the study area exceeded acceptable values, located to the north we se of Quanyan.

The adult female hazard region $(\mathrm{HQ}<1)$ approximately overlaps the male hazard region (Fig. 8). However, the maximum HQ for females and males is 1.19 and 1.04, respectively. Therefore, the risk to adult males is lower as compared to that of adult females, which is attributed to physiology. This finding corresponds to those of the

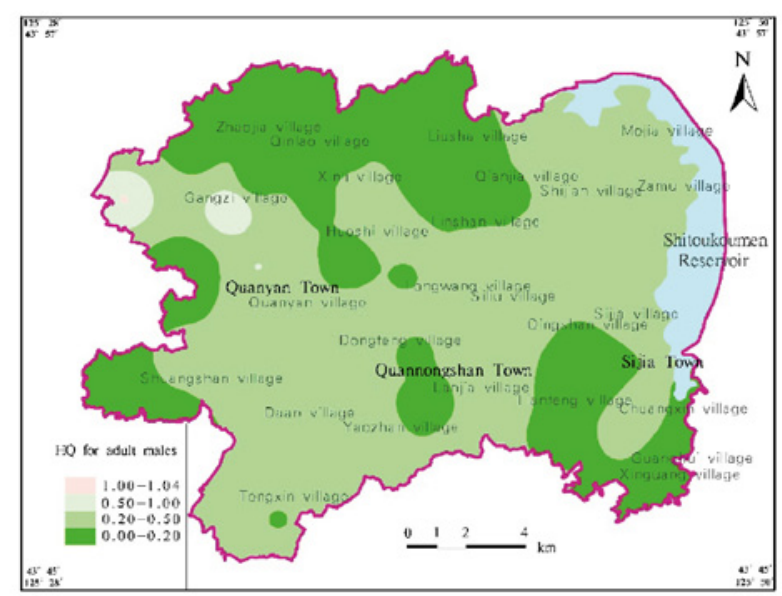

Fig. 7. Distributions of HQs for adult males in the study area.
Weining Plain in northwestern China [52] and highlight the importance of gender in the HHRA process.

\section{Health Risk of Children and Infants}

The health risks to minors are significantly higher as compared to adults and the HQ values for infants and children are shown in Fig. 10. For infants, $66 \%$ of the study area has an acceptable HQ level; distributed near the towns of Quannongshan, Sijiazi, and the north of Quanyan. However, this indicates that $34 \%$ of the region has an unacceptably high infant HQ; distributed to the most areas of Quanyanand the west of Quannongshan town. It is worth noting that HQ values in this area range from 1.25-4.15, indicating that infants in this area have a high potential health risk. HQ values for children are lower as compared to infants, with a maximum of 2.44 . The area of unacceptable HQ is reduced (accounting for $14 \%$ of the total area); distributed in the northwestpart of Quanyan and the western part of Quannongshan town (Fig. 9).

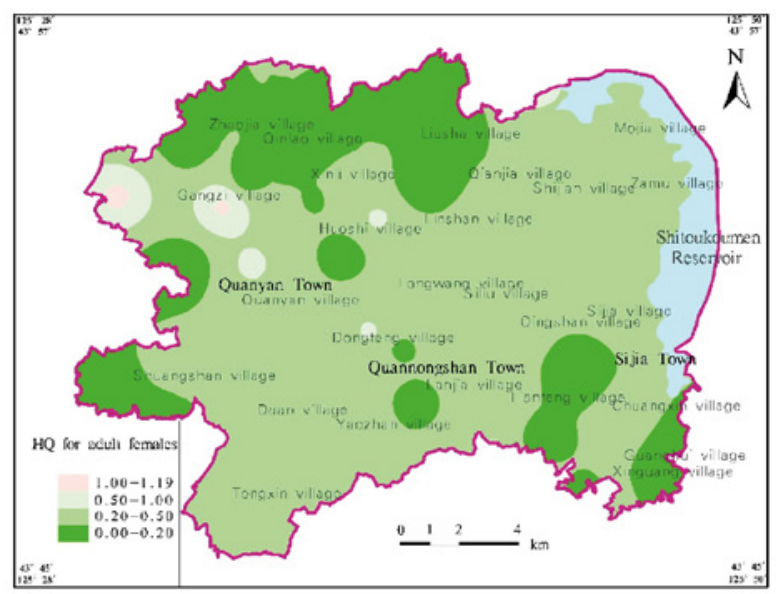

Fig. 8. Distributions of HQs for adult females in the study area. 


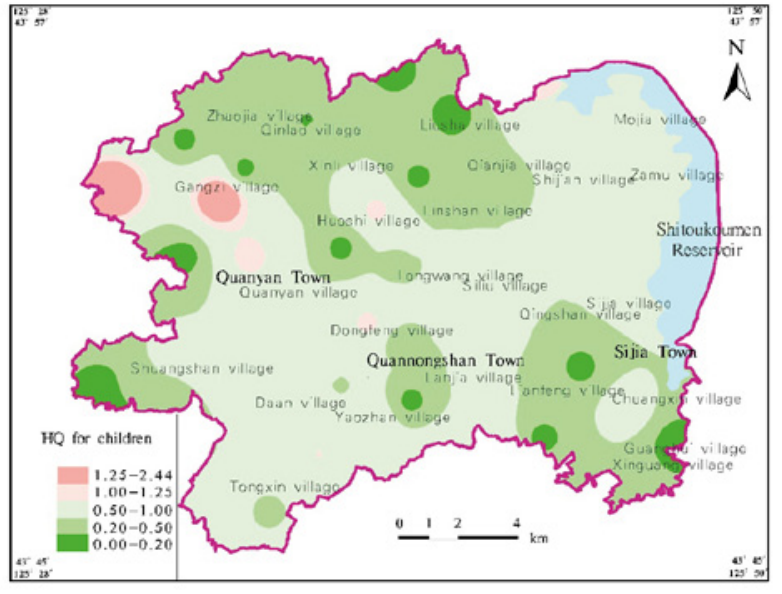

Fig. 9. Distributions of HQs for children in the study area.

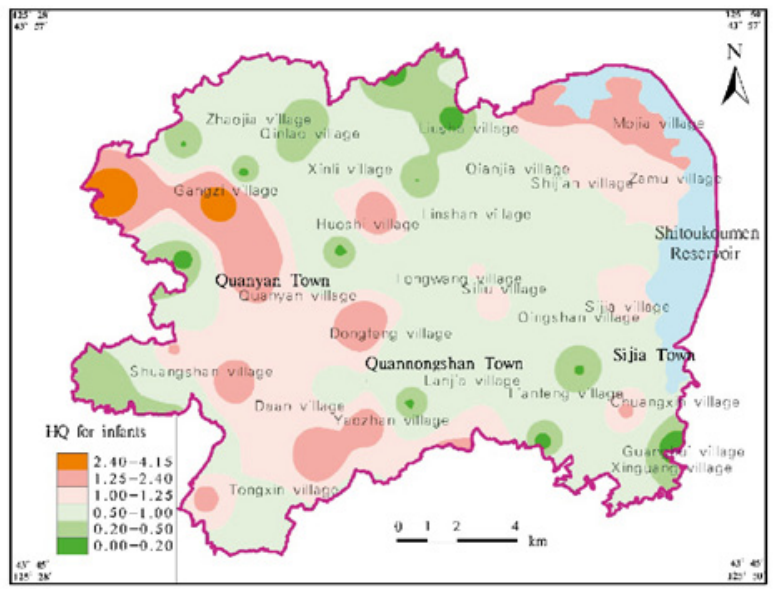

Fig. 10. Distributions of HQs for infants in the study area.

Minors in the study area were markedly more at risk of $\mathrm{NO}_{3}$ contamination as compared to the adult population. Our results correspond with those of Chen et al. [53], who found that infants were the most vulnerable to $\mathrm{NO}_{3}$ exposure via consumption. The increased hazard to minors can be attributed to higher gastrointestinal absorption rates as a result of groundwater-related activities, and an increased sensitivity per unit of body weight exposed to environmental pollutants as compared to adults.

In summary, low $\mathrm{NO}_{3}$ concentrations are distributed near the towns of Quannongshan and Sijiazi, indicating that regional health risks close to urban areas are low. Under normal circumstances, when faced with groundwater $\mathrm{NO}_{3}$ pollution, the health hazards of different populations differ markedly, in the order of infants $>$ children $>$ adult women $>$ adult males .

\section{Conclusions}

Through the analysis of the main chemical components of groundwater in the Lianhuashan District (southeast of Songnen Plain), we determined that the groundwater environment in the study area was weakly acidic ( $\mathrm{pH}$ range of 6.25-7.19 and average of 6.67). Concentrations of the main groundwater components were in the order of TDS $>\mathrm{HCO}_{3}>\mathrm{Ca}>\mathrm{Cl}>\mathrm{SO}_{4}>\mathrm{Na}>\mathrm{Mg}>$ $\mathrm{NO}_{3}>\mathrm{K}>\mathrm{NH}_{4}>\mathrm{NO}_{2}$. Calcium was the most prolific cation (maximum $202 \mathrm{mg} / \mathrm{L}$ ) and $\mathrm{HCO}_{3}$ was the highest anion (maximum $319 \mathrm{mg} / \mathrm{L}$ ). According to the Piper threeline diagram, cations in groundwater were dominated by $\mathrm{Ca}$ and $\mathrm{Na}$, and anions by $\mathrm{HCO}_{3}$ and $\mathrm{Cl}$, indicating that groundwater was of the type $\mathrm{Ca} \cdot \mathrm{Na}-\mathrm{HCO}_{3} \cdot \mathrm{Cl}$. Statistical analysis of groundwater trinitrogen showed that $\mathrm{NO}_{3}$ had marked spatial variability (range of $0.00-340.49 \mathrm{mg} / \mathrm{L}$, and average of $70.38 \mathrm{mg} / \mathrm{L}$ ). More than $28.76 \%$ of the samples exceed Class III values $(20 \mathrm{mg} / \mathrm{L} \mathrm{N})$, and groundwater samples demonstrated higher contamination levels. PCA showed that there was a positive correlation between $\mathrm{NO}_{3}$ and $\mathrm{Cl}, \mathrm{SO}_{4}, \mathrm{HCO}_{3}$, and $\mathrm{Ca}$. High levels of $\mathrm{NO}_{3}$ in the study area were attributed to human activities, including the excessive use of agricultural fertilizers and the discharge of domestic sewage.

Groundwater $\mathrm{NO}_{3}$ data were selected for HHRA. Results showed that the HQ of adult males and females ranged from $0-1.04$ and $0-1.19$, respectively. Approximately $94 \%$ of the adults in the region have an acceptable health risk, while high risk areas were in the northwest of Quanyan town. Regional health risks were in the order of Quanyan>Quannongshan $>$ Sijiazi. The HQ of children and infants ranged from $0-2.44$ and $0-4.15$, respectively. We determined that $86 \%$ of children in the region have an acceptable level of health risk while only $66 \%$ of infants do. Health risks close to urban areas tended to be small. In terms of groundwater $\mathrm{NO}_{3}$ exposure, the health risks of different populations differed markedly in the order of infant $>$ child $>$ adultwoman $>$ adult male.

It is worth noting that there are uncertainties inherent in HHRA, including the temporal and spatial distribution of nitrates, exposure pathways, and parameter selection. It is hoped that this research will attract the attention of government departments and facilitate the adoption of effective measures to reduce the excessive use of agricultural fertilizers, improve the quality of groundwater, and improve human health.

\section{Acknowledgments}

This work was supported by a project of Geological Environment Survey in Changji Economic Circle (No. DD20160265). We thank Yonggen Zhang, Shanghai $\mathrm{Du}$, Zhuang Kang and Haiyang He for helping us with mapping and writing skills in the process of writing this paper. We are also grateful to valuable comments and suggestions given by the editors and the anonymous reviewers. 


\section{Conflict of Interest}

The authors declare no conflict of interest

\section{References}

1. GU B., GE Y., CHANG S.X., LUO W., CHANG J. Nitrate in groundwater of China:sources and driving forces. Glob. Environ. Change. 23, 1112, 2013.

2. ZHAI Y.,LEI Y.,ZHOU J., LI M., TENG Y. The spatial and seasonal variability of the groundwater chemistry and quality in the exploited aquifer in the Daxing district. Environ. Monit. Assess. 2, 1, 2015.

3. LI P., QIAN H.,HOWARD K.W.F., WU J. Building a new and sustainable "Silk Road economic belt". Environ. Earth Sci. 74, 7267, 2015.

4. HAMED Y., AWAD S., SAAAD A.B. Nitrate contamination in groundwater in the SidiAïch-Gafsa oases region, Southern Tunisia. Environmental Earth Sciences. 70, 2335, 2013.

5. SAMANI A.N., MAHMOODI N., MAHDAVI M. Assessment of the Contribution of N-Fertilizers to Nitrate Pollution of Groundwater in Western Iran (Case Study: Ghorveh-Dehgelan Aquifer). Water. Qual. Expo. Health. 7, 143, 2015.

6. China Statistical Yearbook 2016:http://www.stats.gov.cn/ tjsj/ndsj/2016/indexch.htm.

7. DWIVEDI U.N., MISHRA S., SINGH P., TRIPATHI R.D. Nitrate Pollution and its Remediation. Environmental Bioremediation Technologies. 353, 2007.

8. KUMAZAWA K. Nitrogen fertilization and nitrate pollution in groundwater in Japan: Present status and measures for sustainable agriculture. Nutrient Cycling in Agroecosystems. 63, 129, 2002.

9. HAN G. Study on health risk assessment of groundwater environment in a certain area of Cheng Du. Chengdu University of technology, 2014 [In Chinese].

10. GAO J., ZHANG L., HUANG S., MA M., WANG Z. Preliminary assessment of the health risk of metal contamination in drinking water source in Beijing City. Environ. Sci. 25, 47, 2004. (in Chinese with English abstract).

11. NI L.,WANG H., LI X., LIANG J. Environmental health risk assessment of drinking water source in lakes. Environ.Sci. Res. 23,7 4, 2010. (in Chinese with English abstract).

12. QIN W., YANG Z. Health risk assessment of drinking water in Jiangxi Pan Lake area. Mod. Geol. 25, 182, 2011. (in Chinese with English abstract).

13. KONG S., LU B., JI Y., ZHAO X., BAI Z., XU Y., LIU Y., JIANG H. Risk assessment of heavy metals in road and soil dusts within PM20.5, PM10 and PM100 fractions in Dongyingcity, Shandong Province. (China) J. Environ. Monit. 14, 791, 2012.

14. HUANG B.,LI Z., CHEN Z., CHEN G., ZHANG C., HUANG J., NIE X., XIONG W., ZENG G. Study and health risk assessment of the occurrence of iron and manganese in groundwater at the terminal of the Xiangjiang River. Environ. Sci. Pollut. Res Int. 22, 19912, 2015.

15. WANG W.H., ZHAO C., ZHAO J.X. Heavy metal pollution characteristics and ecological risk assessment of a rare earth tailings pond in Baotou. (China) J. Metal Mine. 46, 168, 2017.
16. ZHANG W., YAN Q.W., HUANG R.L. Heavy metal pollution and plant accumulation characteristics of farmland soil in Dabaoshan mining area. (China) J.Soil.49,141,2017.

17. LU JIN, ZHAO XINGQING Heavy Metal Pollution Characteristics and Ecological Risk Assessment of the Shizishan Mining Area in Tongling. (China) J. Environmental Chemistry, 36, 1958, 2017.

18. MAN Y.B., CHOW K.L., WANG H.S., LAU K.Y., SUN X.L., WU S.C., CHEUNG K.C., CHUNG S.S., WONG M.H. Health risk assessment of organochlorine pesticides with emphasis on DDTs and $\mathrm{HCHs}$ in abandoned agricultural soils. J. Environ. Monit. 13, 2250, 2011.

19. LI P.H., KONG S.F., GENG C.M., HAN B., LU B., SUN R.F., ZHAO R.J., BAI Z.P. Health risk assessment for vehicle inspection workers exposed to airborne polycyclic aromatic hydrocarbons (PAHs) in their work place. Environ. Sci.: Process. Impacts 15, 623, 2013.

20. HAN L., QIAN L., YAN J., LIU R., DU Y., CHEN M.A comparison of risk modeling tools and a case study for human health risk assessment of volatile organic compounds in contaminated groundwater. Environ. Sci. Pollut. Res. Int. 23, 1234, 2016.

21. GRUNG M., LIN Y., ZHANG H.,STEEN A.O., HUANG J., ZHANG G., LARSSEN T. Pesticide levels and environmental risk in aquatic environments in China - a review. Environ. Int. 81, 87, 2015.

22. CHEN J.Y. South of Hebei plain groundwater nitrate pollution and its health risk assessment. Environmental Earth Science. 59, 1023, 2010.

23. ZHOU Y.H., WEI A.H., LI J.F., YAN L.D., LI J. Groundwater Quality Evaluation and Health Risk Assessment in the Yinchuan Region, Northwest China. Exposure and Health. 8, 443, 2016.

24. CHEN J.,WU H., QIAN H. Groundwater Nitrate Contamination and Associated Health Risk for the Rural Communities in an Agricultural Area of Ningxia, Northwest China. Exposure and Health. 8, 349, 2016.

25. CHEN J.,WU H., QIAN H., GAO Y.Y. Assessing Nitrate and Fluoride Contaminants in Drinking Water and Their Health Risk of Rural Residents Living in a Semiarid Region of Northwest China. Exposure and Health. 9,1 83, 2017.

26. SU X.S., WANG H., ZHANG Y.L. Health Risk Assessment of Nitrate Contamination in Groundwater: A Case Study of an Agricultural Area in Northeast China. Water Resour Manage. 27, 025, 2013.

27. ZHAI Y.Z., ZHAO X.B., TENG Y.G., LI X., ZHANG J.J., WU J., ZUO R. Groundwater nitrate pollution and human health risk assessment by using HHRA model in an agricultural area, NE China. Ecotoxicology and Environmental Safety. 137, 130, 2017.

28. MAHMOUD M.T., HAMOUDA M.A., AL K.R.R., MOHAMED M. Health Risk Assessment of Household Drinking Water in a District in the UAE. Water. 10, 1684, 2018.

29. ZHANG H.,WU C.Q., GONG J.P., YUAN X.Y., WANG Q., PEI W.M., LONG T.,QIU J., ZHANG H.P. Assessment of Heavy Metal Contamination in Roadside Soils Along the Shenyang-Dalian Highway in Liaoning Province, China. Pol. J. Environ. Stud. 26, 1539, 2017.

30. JAVAID A., AHMAD S.R., QADIR A. Health Risk Surveillance of Arsenic in Wastewater,Groundwater, and Agricultural Land along Hudaira Drain, Pakistan Using GIS Techniques. Pol. J. Environ. Stud. 28, 681, 2019. 
31. DZULFAKAR M.A., SHAHARUDDIN M.S., MUHAIMIN A.A., SYAZWAN A.I. Risk Assessment of Aluminum in Drinking Water between Two Residential Areas. Water. 3, 882, 2011.

32. HUANG Y., ZUO R., LI J., WU J., ZHAI Y.Z., TENG Y.G. The Spatial and Temporal Variability of Groundwater Vulnerability and Human Health Risk in the Limin District, Harbin, China. Water. 10, 686, 2018.

33. WU J.H., MAN Y., SUN G.Y., SHANG L.H. Occurrence and Health-Risk Assessment of Trace Metals in Raw and Boiled Drinking Water from Rural Areas of China. Water. 10, 641, 2018.

34. HUANG S.H., YUAN C.Y., LI Q., YANG Y., TANG C.J., OUYANG K., WANG B. Distribut-ion and Risk Assessment of Heavy Metals in Soils from a Typical PbZn Mining Area. Pol. J. Environ. Stud. 26, 1105, 2017.

35. JAVED T., AHMAD N., MASHIATULLAH A. Heavy Metals Contamination and Ecological Risk Assessment in Surface Sediments of Namal Lake, Pakistan. Pol. J. Environ. Stud. 27, 675, 2018.

36. LI Z.,BI E., ZHANG S., YIN M., MA L., WANG W., ZHANG Y. Method for health risk assessment of groundwater pollution. South-to-North Water Transf. Water Sci. Technol. 6, 47, 2008 (in Chinese with English abstract).

37. CHEN J., WU H., QIAN H., GAO Y. Assessing nitrate and fluoride contaminants in drinking water and their health risk of rural Residents living in a semiarid region of Northwest China. Expo. Health. http://dx.doi.org/10.1007/ s12403-016-0231-9. 2016.

38. USEPA (US Environmental Protection Agency).Guidelines for carcinogen risk assessment. Risk Assessment Forum. 2005.

39. USEPA (US Environmental Protection Agency).Risk assessment guidance for Superfund volume III: Part A,process for conducting probabilistic risk assessment. 2001.

40. YANG M., FEI Y., JU Y., MA Z., LI H. Health risk assessment of groundwater pollution - a case study of typical city in North China plain. J. Earth Sci. 23, 335, 2012.

41. USEPA (US Environmental Protection Agency). Risk assessment guidance for Superfund, Volume I: Human Health Evaluation Manual (Part A). 1989.

42. USEPA (US Environmental Protection Agency).Risk assessment guidance for Superfund: Volume I: Human Health Evaluation Manual (Part B,Development of RiskBased Preliminary Remediation Goals). Interim Final. December. 1991b.
43. USEPA (US Environmental Protection Agency).Risk assessment guidance for Superfund,Volume I: Human Health Evaluation Manual (Part E, Supplemental Guidance for Dermal Risk Assessment) Final. 2004.

44. ZHANG H. Nitrate contamination of groundwater in Southern Hebei Plain and its Health risk assessment. Institute of Geographical Sciences and Natural Rescoures Research, (in Chinese with English abstract) 2008.

45. ZAKHEM B.A., HAFEZ R. Hydrochemical, isotopic and statistical characteristics of groundwater nitrate pollution in Damascus Oasis (Syria). Environ. Earth Sci. 74, 2781, 2015.

46. NAKAGAWA K., AMANO H., ASAKURA H., BERNDTSSON R. Spatial trends of nitrate pollution and groundwater chemistry in imabara, Nagasaki. Jpn. Environ. Earth Sci. 75, 1, 2016.

47. JALALI M. Nitrate pollution of groundwater in Toyserkan, western Iran. Environ. Earth Sci. 62, 907, 2011.

48. FABRO A.Y.R., ÁVILA J.G.P., ALBERICH M.V.E., SANSORES S.A.C., CAMARGO-VALERO M.A. Spatial distribution of nitrate health risk associated with groundwater use as drinking water in Merida, Mexico. Appl. Geogr. 65, 9, 2015.

49. BABIKER I.S., MOHAMED M.A.A., TERAO H., KATO K., OHTA K. Assessment of groundwater contamination by nitrate leaching from intensive vegetable cultivation using geographical information system. Environ. Int. 29, 1009, 2004.

50. LASAGNA M., DEL., FRANCHINO D.A. Nitrate contamination of groundwater in the western Po Plain (Italy): the effects of groundwater and surface water interactions. Environ. Earth Sci. 75, 1, 2016.

51. RAHMATI O., SAMANI A.N., MAHMOODI N., MAHDAVI M. Assessment of the contribution of Nfertilizers to nitrate pollution of groundwater in Western Iran (case study: Ghorveh-Dehgelan aquifer).Water Qual., Expo. Health. 7, 143, 2014.

52. LI P.,LI X., MENG X., LI M., ZHANG Y. Appraising groundwater quality and health risks from contamination in a semiarid region of Northwest China. Expo. Health. http://dx.doi.org/10.1007/s12403-016-0205-y. 2016.

53. CHEN J., TANG C., SAKURA Y., YU J., FUKUSHIMA Y. Nitrate pollution from agriculture in different hydrogeological zones of the regional groundwater flow system in the North China Plain. Hydrogeol. 13, 481, 2005. 